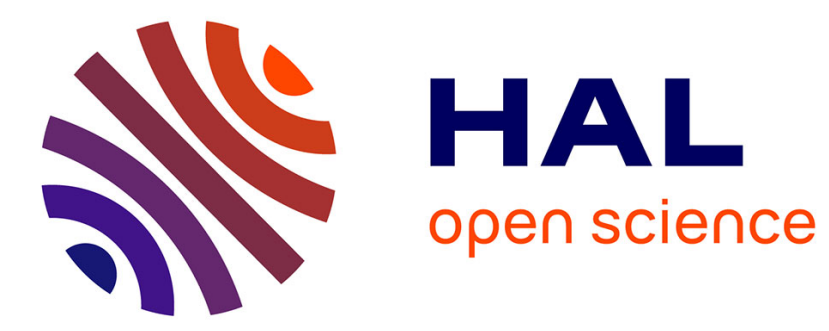

\title{
IMPLICIT BANDS IN THE YEN/DOLLAR EXCHANGE RATE
}

Francisco Ledesma-Rodríguez, Manuel Navarro-Ib ez, Jorge Pérez-Rodríguez, Simon Sosvilla-Rivero

\section{- To cite this version:}

Francisco Ledesma-Rodríguez, Manuel Navarro-Ib ez, Jorge Pérez-Rodríguez, Simon Sosvilla-Rivero. IMPLICIT BANDS IN THE YEN/DOLLAR EXCHANGE RATE. Applied Economics, 2009, pp.1. 10.1080/00036840802600384 . hal-00582271

\section{HAL Id: hal-00582271 \\ https://hal.science/hal-00582271}

Submitted on 1 Apr 2011

HAL is a multi-disciplinary open access archive for the deposit and dissemination of scientific research documents, whether they are published or not. The documents may come from teaching and research institutions in France or abroad, or from public or private research centers.
L'archive ouverte pluridisciplinaire HAL, est destinée au dépôt et à la diffusion de documents scientifiques de niveau recherche, publiés ou non, émanant des établissements d'enseignement et de recherche français ou étrangers, des laboratoires publics ou privés. 


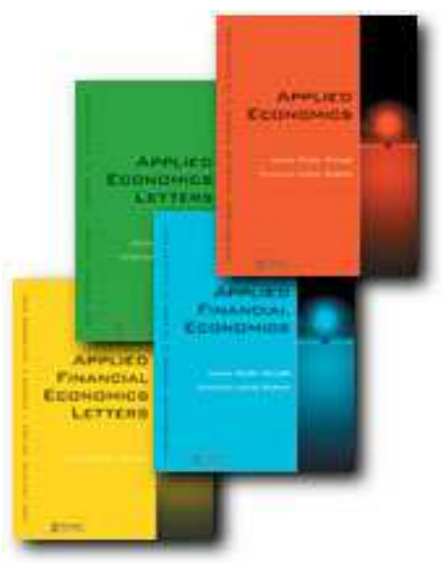

\section{IMPLICIT BANDS IN THE YEN/DOLLAR EXCHANGE RATE}

\begin{tabular}{|r|l|}
\hline Journal: & Applied Economics \\
\hline Manuscript ID: & APE-07-0641.R1 \\
\hline Journal Selection: & Applied Economics \\
\hline Date Submitted by the \\
Author: & 27-Oct-2008 \\
\hline Complete List of Authors: & $\begin{array}{l}\text { Ledesma-Rodríguez, Francisco; Universidad de La Laguna, Analisis } \\
\text { Economico } \\
\text { Navarro-Ibáñez, Manuel; Universidad de La Laguna, Analisis } \\
\text { Economico } \\
\text { Pérez-Rodríguez, Jorge; Universidad de Las Palmas de Gran } \\
\text { Canaria, Metodos Cuantitativos } \\
\text { Sosvilla-Rivero, Simon; FEDEA }\end{array}$ \\
\hline JEL Code: & $\begin{array}{l}\text { F33 - International Monetary Arrangements and Institutions < F3 - } \\
\text { Exchange < F3 - International Finance < F - International } \\
\text { Economics }\end{array}$ \\
\hline Keywords: & Exchange rate regimes, Implicit fluctuation bands, Exchange rates \\
\hline
\end{tabular}

\section{scholarONE" \\ Manuscript Central}




\title{
IMPLICIT BANDS IN THE YEN/DOLLAR EXCHANGE RATE*
}

\author{
Francisco Ledesma-Rodríguez \\ (Universidad de La Laguna) \\ Manuel Navarro-Ibáñez \\ (Universidad de La Laguna) \\ Jorge Pérez-Rodríguez \\ (Universidad de Las Palmas de Gran Canaria) \\ Simón Sosvilla-Rivero \\ (FEDEA and Universidad Complutense de Madrid) \\ (Revised version, October 2008)
}

\begin{abstract}
This paper attempts to identify implicit exchange rate regimes for the Yen/Dollar exchange rate. To that end, we apply a sequential procedure that considers both the dynamics of exchange rates and central bank interventions to data covering the period from 1971 to 2003. Our results suggest that implicit bands existed in two subperiods: April-December 1980 and March-October 1987, the latter coinciding with the Louvre Accord. Furthermore, the study of the credibility of such implicit bands indicates the high degree of confidence attributed by economic agents to the evolution of the Yen/Dollar exchange rate within the detected implicit band rate, thus lending further support to the relevance of such implicit bands.
\end{abstract}

JEL classification: F31; F33

Keywords: Exchange rate regimes, implicit fluctuation bands, exchange rates.

\footnotetext{
* The authors wish to thank two anonymous referees and Mark Taylor for helpful comments and suggestions on a previous draft of this paper, substantially improving the content and quality of the paper. We are also in debt to Christopher Neely (Federal Reserve Bank of St. Louis) for kindly providing the data set on official interventions used in this paper. Financial support from the Spanish Ministry of Science and Technology (SEJ2005-09094/ECON) is also gratefully acknowledged. The views expressed here are those of the authors and not necessarily those of the institutions with which they are affiliated.
} 


\section{Introduction}

The de facto exchange rate policy adopted by monetary authorities has tended to differ from the announced de jure exchange rate regime, which is why IMF classifications are not always a good guide to the true exchange rate intentions of said authorities.

The literature in this area seeks to achieve two linked objectives, namely, to detect divergences between de jure and de facto regimes and to assess the consequences of these differences on the relevance of exchange rates for macroeconomic performance $^{1}$. Recognition of the divergences opens up a number of key questions regarding the analysis and recommendations of international economic organizations as well as for academic work: which is the correct classification and which variables and methods should be considered for this purpose?

Recently, Reinhart and Rogoff (2004) have presented a comprehensive classification of the exchange rate regimes of 153 countries over the last half-century. Their research suggests the importance of de facto bands in the international economy. Other approaches focus on the variation of central bank reserves and acknowledge the relevance of intervention in detecting implicit pegs and bands (see, for instance, Poirson, 2001).

The main objective of this paper is to use a sequential procedure that considers both the dynamics of exchange rates and central bank interventions to detect implicit bands for the Yen/Dollar exchange rate.

We analyse the Yen/Dollar exchange rate as a interesting case study since it has traditionally been considered a paradigmatic example of a flexible exchange rate (see e.g. Cooper, 1999). Notwithstanding the customary consideration of the Yen/Dollar exchange rate as free-floating, a number of studies ${ }^{2}$ have examined the behaviour of the US Federal Reserve and the Japanese monetary authorities in exchange rate markets and the effectiveness of such intervention in driving the Yen/Dollar exchange rate.

This paper is organized as follows. To place the study in its proper context, Section 2 presents a brief history of exchange rate regimes. In Section 3 we propose a test to detect implicit band and to assess the statistical significance of the Reinhart and Rogoff (2004) approach. In addition, we apply two tests to interventions and to exchange rate data to assess both the intention and the efficacy of foreign exchange market interventions. Section 4 examines the credibility of the implicit bands found in Section 3. Finally, Section 5 provides some concluding remarks.

\footnotetext{
${ }^{1}$ See Coudert and Dubert (2004) for a survey of studies on implicit exchange rate regimes. Reinhart and Rogoff (2004) examine the relevance of the exchange rate regime classifications for empirical macroeconomics.

${ }^{2}$ For example, Ito and Yabu (2004) and Frenkel et al. (2004) estimate the Japanese monetary authorities' reaction function.
} 


\section{Exchange rate regimes}

The relationship between a country's exchange rate regime and its macroeconomic performance has been discussed extensively ever since the collapse of the Bretton Woods system. After the prolonged period of fixed exchange rates which characterized the system, many anticipated a generalisation of more flexible regimes in the belief that these were better equipped to protect the economy from real and monetary shocks. Instead, however, in several countries the monetary authorities pegged the external value of their currencies to the Dollar, the Yen, the Pound Sterling, or to a basket of currencies, believing that greater exchange rate flexibility led to excessive fluctuations. Such volatility was considered to give rise to economic instability, having a negative impact on productive investment, international trade and growth.

During the 1980s, monetary authorities adopted their exchange rate regimes with the clear intention of seeking a sound stabilisation instrument to protect against real and monetary shocks. In particular, they expected that fixing the exchange rate would prevent excessive monetary growth, thus conferring greater discipline on public spending (Levy-Yeyati and Sturzenegger, 2001). The widespread monetary instability experienced during the period called for disinflation and budget consolidation policies and it was no surprise that monetary considerations attracted more attention.

The series of crises in the 1990s led to many to once again question the appropriateness of pegged exchange rates. More flexible systems were now considered more adequate than their fixed counterparts as a means of protection against speculative pressures. This change in perspective stemmed from the growing importance of movements of private capital between countries, a circumstance which had a profound impact on the international financial system. The crises experienced during these years centred on the evolution of the capital account, in contrast to the previous decades, when more traditional causes -high fiscal deficits and the ensuing monetisation, distortions in goods and services markets, as well as production market factors, among others- were paramount (Summers, 2000).

In this context, this paper aims to study the exchange rate regimes followed by the Yen/Dollar exchange rate. The monetary and trade relationships between Japan and US have been difficult in different periods of their recent history. The monetary policy pursued by the Federal Reserve seems to have been quite independent while the Japanese monetary policy appears instead to have been conditioned by the appreciating trend of the Yen with respect to the Dollar (Glick and Hutchinson, 1994). This trend may explain the differences, at least since 1971, between Japan and the US in trade policy and the financial pressures due to the accumulation of external surpluses. The observed appreciation of the Yen and the expectations of further appreciations might be reasons for the deflationary monetary policy of Japan at the end of the seventies.

Before the fall of Bretton-Woods, the sharp appreciation of the Yen implied better competitiveness for US industrial goods. As a response, the Bank of Japan reduced the short-term interest rates in order to switch this trend. The Japanese economy entered in an unstable period due to the depreciation, and expectations of further depreciation, of the Yen and the increasing risk derived from the accumulation of assets denominated in dollars by the Japanese financial institutions. 
In the 1990s the Japanese economy seemed to be in a liquidity trap externally imposed. Economists and practitioners alike were unable to identify the true origins of the crisis in which consumption and investment were weakened; in fact, this lack of knowledge is one of the most important failures of modern macroeconomics (McKinnon, 2000). In this period, Japan suffered high rates of unemployment and deflation, as well as low growth. In fact, the 1990s has been considered "a lost decade" by Hiyashi and Prescott (2002).

The choice of the exchange rate regime which every country has to make has also centred empirical discussion on the appropriate estimation of the economic costs and benefits of different systems. A difficulty that often arises concerns the wide range of possibilities since there are more than two or three regimes (in contrast to the approach taken in the numerous studies which naturally employed the official IMF classification). Rather, countries use a range of exchange rate systems, such as currency boards, narrow bands, moving or crawling bands, and managed floats.

To all these should be added another difficulty which has come to light more recently: many countries do not declare the true system used. The exchange rate policy followed de facto by numerous countries has been found to be vastly different to what was officially notified to the IMF by the economic authorities. Many countries experience what Calvo and Reinhart (2002) have called the "fear of floating", namely, they do not really allow their exchange rates to move freely, regardless of the de jure exchange rate system reported by the authorities to the IMF.

One of the consequences of this divergence between "deeds" and "words" (Levy-Yeyati and Sturzeneger, 2000; 2001) has been to call into question the results of many empirical studies based on the IMF classification. For this reason, before proceeding any further with an evaluation of the different exchange rate regimes, a classification of the de facto systems is needed to replace the de jure systems used until recently by researchers in the field of International Economics.

One of the aims of this paper is to identify implicit band or peg regimes. Specifically, we examine the possible existence of fluctuation bands, "agreed" by the monetary authorities in order to intervene in the Yen/Dollar market during the period 1971-2003. In this regard, Fischer (2001), for example, has pointed to the possibility that a commitment to maintain a desired exchange rate target zone between the US Dollar, the Euro (the Deutsche Mark previously) and the Yen may have existed, albeit informally and loosely.

According to the literature on optimum currency area, the most appropriate regime may vary in each circumstance, attending to the nature of disequilibria suffered by an economy, the capacity to transmit or isolate from internal or external shocks, and the ability of economic authorities to use different instruments of economic policy (see, for instance, Horvath, 2003). The observed exchange rate system might be related to concrete episodes and the economic policy used as a response. This literature may provide a good guide to interpret the de facto deviations from the de jure exchange rate regime. In this sense, flexible exchange rates could be preferable when real shocks, both domestic and external, occur while fixed regimes seems to perform better when shocks are merely nominal (Buiter, 1995). A smaller degree of trade openness reduces the possible damage done to internal price stability and to the external balance of a country 
due to exchange rate variability (McKinnon, 1963). Also a small product diversification increases the likelihood of asymmetric shocks and so the need for exchange rate flexibility (Kenen, 1969), and it is more difficult to fix the exchange rate if the inflation rates of the two countries are quite dissimilar and prices and wages are sticky (Fleming, 1971). Lastly, pegging the exchange rate can provide a reasonably credible commitment to a non-inflationary policy but, as indicated by Stockman (1999), there are alternative institutional arrangements that have shown a better performance.

\section{Implicit bands}

\subsection{Detection of implicit bands}

Reinhart and Rogoff (2004) proposed a "natural" classification of exchange rate regimes, as opposed to the "artificial" one followed by the IMF. In their extensive research they collected monthly data on the exchange rates of 153 countries from 1946 to 2001, highlighting the existence of dual, multiple, or even parallel (legally or otherwise) rates. In the event of the absence of a dual market to adequately classify the de facto regimes, their approach based the search for peg or band regimes on the proportional variation of the absolute value of the exchange rate, as well as on the probability that it would remain within a given fluctuation band $( \pm 1 \%, \pm 2 \%$ or $\pm 5 \%)$ over a rolling 2 or 5 -year period. Reinhart and Rogoff, somewhat surprisingly, focus on the evolution of exchange rates, without taking into account variations in official foreign currency reserves.

One of the weaknesses of the approach taken by Reinhart and Rogoff (2004) is that the results are not filtered by their statistical significance. For this reason we perform a variant approach to detect implicit pegs or bands that involves direct testing to see whether the average of the proportional absolute monthly variations for each rolling 24-month period is significantly less than $\pm 1 \%$ or $\pm 2 \%$. To test if the population mean (of the monthly variations during 24-month periods) is less than or equal to a given mean $\mu_{0}( \pm 1 \%$ or $\pm 2 \%)$ the following expression may be used:

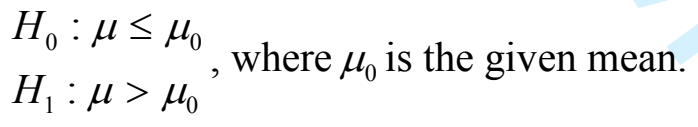

The acceptance region of the null hypothesis is $\bar{x} \leq \varepsilon$, where $\bar{x}$ is the sample mean of the Yen/Dollar exchange rate and $\varepsilon=\mu+t_{1-\alpha, n-1} \frac{\sigma}{\sqrt{n}}$, where $t_{1-\alpha, n-1}$ is the critical value of the t-Student distribution at a confidence level of $1-\alpha, \sigma$ is the serial population deviation and $n$ is the sample size. At a $5 \%$ confidence level we choose a critical value of 1.71 . and 2 .

The results of the application of this statistical procedure are given in Figures 1

[Figure 1, here]

Figure 1 show the results when $\pm 1 \%$ fluctuation bands are considered. The average value (24 months rolling) of absolute proportional variations of the exchange rate of each month with respect to the previous month is given in blue, while the critical 
region appears in red. Thus, when the red series is above the blue one the null hypothesis cannot be rejected, which would suggest the presence of fluctuation bands. This occurs around the Bretton Woods period but extends until the end of 1977. With respect to the first years of the 1970s, any observer could argue that the Japanese economy was suffering a real shock due to the increase of the crude oil prices, and therefore the convenience of a flexible exchange rate. However the oil shock only had a temporary impact due to the rapid response of the Bank of Japan (Meltzer, 1986), quite different from the more permanent character of the monetary shock produced at the end of the Bretton Woods system (Hetzel, 2004); in this sense its temporary character would have made more appropriate a de facto regime. Furthermore, the small size of the Japanese economy compared to the US, its lesser diversification of production, and its continuous external surplus could explain why the Japanese monetary authorities optimally chose less flexibility for their exchange rate, as suggested by Aghion et al. (1999) and Bachetta (2000).

Likewise, between 1983 and 1985, between 1995 and 1997, and at the end of the sample period the results indicate that the regime was in the neighbourhood of the $\pm 1 \%$ fluctuation band. In particular, during 2003 the Japanese economy was in a deep deflationary process, aggravated by a zero interest rate policy (Ito and Mishkin, 2004); and, in this context, Svensson (2003) pointed out that the Bank of Japan made a commitment of maintaining a level of the exchange rate compatible with the objective of affecting agent expectations. This non-conventional monetary policy and the fact that the deflation had its origin in a domestic monetary shock (Metzler, 2002) could explain the smaller de facto flexibility of the exchange rate in 2003.

[Figure 2, here]

As can be seen in Figure 2, the average of the monthly variations generally lies below the critical region when a $\pm 2 \%$ fluctuation band is used, suggesting (given the rolling quality of the 24-month test) that in practical terms there were monthly limits of $\pm 2 \%$ during the entire period. Combining this result with that observed with the $\pm 1 \%$ band, we can be confident that fluctuation bands between $\pm 1 \%$ and $\pm 2 \%$ existed throughout the sample period, except during the three subperiods detected with the $\pm 1 \%$ test, when the bands were narrower.

\subsection{Sensitivity analysis ${ }^{3}$}

Results from the previous analysis seem reasonable, but monetary authorities could have used an alternative benchmark to define the implicit bands as the deviation from Purchasing Power Parity (PPP).

In its absolute version, PPP theory establishes a relationship between the exchange rate $\left(S_{t}\right.$, expressed as the home currency price of a unit of foreign exchange) and the ratio of domestic and foreign prices $\left(P_{t}\right.$ and $P_{t}{ }^{*}$ respectively), so that

$$
S_{t}=P_{t} / P_{t}^{*}
$$

\footnotetext{
${ }^{3} \mathrm{We}$ are grateful to an anonymous referee for suggesting this sensitivity analysis using deviations from purchasing power parity.
} 
As can be seen, the higher the domestic price level relative to the foreign price level, the higher must be the exchange rate in order to retain purchasing power parity between domestic and foreign currencies.

The absolute PPP is a too restrictive hypothesis for at least two reasons. First, factors such as costs of gathering and processing information, transport costs and other obstacles to trade (in particular tariffs and quotas), and market imperfections can limit spatial arbitrage and therefore account for deviations from absolute PPP. Second, the weights used in the computation of a price level could differ across countries and as a consequence the absolute PPP may be hardly held.

For these reasons, a less restrictive relationship between prices and exchange rate is considered. This is the relative PPP, which asserts that the percentage rate of change of the exchange rate will equal the differential between the percentage rates for change of price levels at home and abroad. That is

$$
\Delta s_{t}=\Delta p_{t}-\Delta p_{t}^{*}
$$

where $\Delta$ denotes first difference and lower-case letters denotes logs. Therefore, if the domestic inflation rate exceeds the foreign inflation rate, a domestic currency depreciation (i.e, an increase in $\Delta s_{t}$ ) is required to sustain purchasing power parity between domestic and foreign currencies. Similarly, if the foreign inflation rate exceeds the domestic inflation rate, this will be associated with a domestic currency appreciation (i.e., a reduction in $\Delta s_{t}$ ).

Relative PPP is less strict than absolute PPP in allowing domestic and foreign prices (expressed in domestic currency) to differ from each other but still sustains the assumption that these deviations will not grow or diminish persistently over time. The relative purchasing power of domestic money vis-à-vis foreign money will therefore be fixed over time, with exchange rate changes $\Delta s_{t}$ assuring such parity. The relative version of PPP has a further advantage over absolute PPP in that as long as the weights used to define the domestic and foreign price indices remain constant over time, then the two weighting schemes do not need to be the same.

We compute an alternative indicator to detect implicit pegs or bands using deviations of observed changes in exchange rates from inflation differential between Japan and USA. Again we test whether the average of the proportional absolute monthly variations of the real exchange rate for each rolling 24-month period is significantly less than $\pm 1 \%$ or $\pm 2 \%{ }^{4}$. Note that this time the sample covers until December 2007, in an attempt to detect any other episode of implicit band in the post-

\footnotetext{
${ }^{4}$ We also explore the possibility of much wider implicit bands, but they were not consistent with the data. As a matter of fact, although the maximum deviation of the observed exchange rate variation from the theoretical exchange rate variation derived from relative PPP (i. e., the inflation differential between Japan and USA) was $10.27 \%$ during the January 1971-December 2007 period, the average deviation was $2.12 \%$ and the median $1.68 \%$, giving further support to the hypothesis of implicit fluctuation bands of $\pm 2 \%$.
} 
Plaza Accord period ${ }^{5}$. Figures 5 and 6 show the results for $\pm 1 \%$ and $\pm 2 \%$ fluctuation bands, respectively.

\author{
[Figures 3 and 4, here]
}

As can be seen, we obtain similar results than in Figures 1 and 2, therefore providing further support to the fluctuation bands we have previously detected.

\title{
3.3. Incorporating interventions
}

In this section we incorporate foreign exchange intervention by monetary authorities into the search for bands in the Yen/Dollar exchange rate. In the previous section, de facto bands or pegs were identified for most of the sample period using an approach based on exchange rate data. This suggests that the results obtained are not informative. Most of the literature that classifies exchange rate regimes also uses exchange rate data or a combination of foreign reserve and exchange rate data. Such analysis either has either not taken central bank interventions into account or has used an imperfect proxy for them so as to detect periods with exchange rate regimes other than a free floating one ${ }^{6}$. An ideal method should, however, consider foreign exchange market interventions to screen both for the intentions of central banks and their efficacy with regard to peg or band regimes ${ }^{7}$.

In spite of its relevance, the availability of intervention data limits its consideration. Here we use Federal Reserve intervention data from 1 January 1980 until 31 December 2003 as well as data from the Japanese Ministry of Finance from 13 May 1991 until 31 March 2001. We consider the intervention to have a positive sign when the monetary authority buys US dollars and a negative one for other actions.

The Pesaran and Timmermann (1992) test is used as a directional prediction test. In this test, the sign of central bank intervention and the exchange rate trend are related, particularly when lagged interventions (to measure efficacy) and leads (to detect the monetary authorities' intention to maintain bands or pegs) are considered relative to the exchange rate trend. In the first case, one would expect the ex ante intervention consisting of the sale of US Dollars to be followed by an appreciation of the Yen. In the second case, the ex post intervention is considered once the trend has been observed,

\footnotetext{
${ }^{5}$ Jeon and Lee (2002) show that within-country market efficiency appears to have become stronger in the post-Plaza agreement period than before and have not been affected by the major foreign exchange policy co-ordinations.

${ }^{6}$ Neely (2000) has shown that central bank interventions and reserve changes may be loosely related. Therefore, the use of reserves instead of interventions may lead to inadequate classifications.

${ }^{7}$ We study the incidence of interventions at the exchange rate level. See Domínguez $(1993,2003)$ for a survey of the literature analyzing the effect of intervention on the volatility of exchange rates. Wan and Kao (2008) find that foreign exchange interventions by the Japanese authorities were effective not only in altering the exchange rate level, but also in volatility reduction. On the other hand, results in Chen and Huang (2007) suggest no significant difference between the effectiveness of joint intervention and independent intervention on the yen/US dollar exchange rate during the 15 August 1996-6 January 1999 period. Finally, Ramchander and Sant (2002) show that Fed intervention is associated with negative changes in the US\$/ volatility during the 1985 to 1993 period as a whole, and specifically during the 1 January, 1985 to 21 February, 1987 Plaza period and the 21 February, 1987 to 31 December, 1989 Louvre period.
} 


\footnotetext{
${ }^{8}$ We adopt this approach because standard time-series techniques may not be appropriate when dealing with the study of foreign market intervention and the associated behaviour of exchange rates. Exchange rates are highly volatile and interventions are usually sporadic (Fatum and Hutchison, 2003, 2005). In contrast, Frenkel et al. (2004) estimate a reaction function for sterilised interventions by the Japanese monetary authorities and find major interventions after 1995 in reaction to the previous exchange rate trend.

${ }_{9}^{9}$ To calculate these frequencies we only consider the number of days in a given month in which the monetary authority intervened.
} 
exchange rates) for most of the values of $k$. In the rest of the sample period the null hypothesis of independence is not rejected.

These conclusions can be confirmed in Panel B, where the efficacy of the interventions is analysed. For several months in 1980, as well as in August of 1987, interventions seemed to have been effective $\mathrm{e}^{1011}$.

Therefore, our results suggest signs of the presence of a target zone in 1980 and 1987. The later year coincides with the time of the Louvre Accord among the leading industrial nations. There are several papers analysing the Louvre Accord as a targetzone experiment due to its commitment towards the coordination of macroeconomic policies in order to stabilize the exchange rates [see, e. g., Ito (1999) and Nakamura (1995)]. However, the presence of bands for the Yen/Dollar exchange rate in 1980 is an episode which has not previously been identified as a period where an implicit band regime was operating. Therefore a background account of such episode is necessary. In this sense, it should be remembered that, in 1979, as inflationary pressures at the wholesale level built up drastically and the current account was pushed deep into deficit, the Yen caved heavily on offer and depreciated sharply in the exchange market. In 1980, the year just after the tripling of oil prices, inflation as measured by the GDP deflator remained at only 5 percent. This suggest that homemade inflation was avoided, confirming that the Bank of Japan (BOJ) had both the ability and the intention to maintain price stability. In this sense, there were a series of coordinated changes in interest rates in the U. S. and Japan that did not leave the Yen/Dollar exchange rate unaltered (Bomhoff, 1987). Trust in the BOJ was preserved, keeping expected inflation at a very low level and the actual inflation not deviating from expectations by any significant amount (Suzuki, 1987 and 1989) ${ }^{12}$. In addition, as documented in Cargill et al. (1997), the BOJ reacted very quickly selling Dollars in support of the Yen, sharply dropping its international reserves. This appreciation helped the Bank of Japan to moderate inflation. Following the adoption of more restrictive fiscal and monetary policies to stabilize the Yen in March, the main central banks announced a closed cooperation to prevent the Yen from declining excessively. By mid-April, with interest rates falling in the United States, the Yen began to recover along with other major currencies [see, e. g., OECD $(1980,1981)$ and Pardee $(1980,1981)]$. In May, the BOJ intervened to counter disorderly conditions. The support of a firm inflationary effort from the new government after parliamentary elections in June reinforced the bank's credibility. Market participants become aware that Japan was achieving a rapid

\footnotetext{
${ }^{10}$ In order to assess the robustness of results, we additionally apply the Fisher's Exact Test. This test of independence (for $2 \times 2$ tables) is used when the members of two independent groups can fall into one of two mutually-exclusive categories. In our case, each day in a given month can fall into one of two categorical variables: the sign of the exchange rate trend and the sign of the intervention. The former may give two levels (appreciation or depreciation of the Yen) while the latter indicates the purchase or sale of Dollars. The results confirm those obtained from the Pesaran-Timmermann test. Again, the results for Japanese interventions are less informative and the independence hypothesis could not be rejected for the whole sample period.

${ }^{11}$ Based on an event study methodology, Fatum and Hutchison (2005) analyse the Yen/Dollar exchange rate and find evidence that intervention affects the rate in the short term. Taylor (2004) also obtains evidence supporting the view that interventions increase the probability of stability (only when the exchange rate is misaligned) in a Markov-switching model.

${ }^{12}$ It should be noted that, despite the aggressive actions taken by the BOJ to contain inflation and the importance of imported crude oil to Japan, the effect of the oil price on output appears to be moderate (Hetzle, 1999), with Japan being the only major industrial country to avoid recession (Cargill et al., 1997).
} 
adjustment to higher world oil prices, the Yen being remarkably resilient in the face of the prospective fall in oil production resulting of hostilities between Iran and Iraq. The BOJ intervened once more in September to moderate the rise of the Yen. After a series of financial measures, and given the strength of exports and investment demand, exchange rate sentiment became more favourable for the yen.

Regarding the directions of interventions during 1980, Schwartz (2000) suggests that the Fed acquired yens in the market from February to March 1980, and from late March it sold yen. By the end of July, the US monetary authorities were ageing accumulating yens. From September 1980 to February 1981, the aim of the Fed was to cushion the rise of dollar, acquiring yens to pay off swap debts. This behaviour is consistent with the detailed account provided in Pardee (1980, 1981):

i) in February the BOJ intervened to moderate the decline of the yen, supplementing its intervention in Tokyo with operations in New York through the Federal Reserve Bank of New York.

ii) in March there was a joint initiative by the BOJ, the FED, the Bundesbank and the Swiss National Bank to support the yen in the exchanges, indicating the FED its willingness to purchase yen in the New York market for its own account and to provide resources to the BOJ if needed. The sales of dollars by the Bank of Japan were reflected in the US\$2.2 billion decline of foreign reserves during February-March. Meanwhile, the Fed bought US\$216.8 million equivalent of yen in the New York market in coordinated operations with the BOJ.

iii) in April the Bank of Japan continued to intervene forcefully to defend the yen, buying back about half of the amount of dollars it sold earlier.

iv) in July, reserves increased by US\$2.0 billion.

v) in late September-early October, the BOJ intervened in the foreign exchange market, due to a substantial improvement in Japan's current account position and to heavy demands for yen-denominated assets, producing the rise of the yen. This operation contributed to a US $\$ 2.2$ billion increase in foreign reserves.

vi) from early November the Yen/Dollar rate started to fluctuate around 212, finally dropping to 216.75. The interventions by the Fed and by the Bank of Japan suggest the presence of a crawling band.

Finally, it should be noted that, although Japan is by far the largest participant government in the foreign exchange market (see Fatum and Hutchison, 2005), the analysis of Japanese interventions was restricted by the availability of data (from March 1991 only). Though quite weak in April and August 1992, which might signal a lack of independence, in general the results do not seem to reject the hypothesis of independence ${ }^{13}$. With respect to the results obtained for 1987 and in relation to the FED, from 1987 up to 1992, Japanese monetary policy appears to have been conditioned by the Louvre Accord. In this sense, it is interesting to recall that large-scale, coordinated interventions, as those implied by the Louvre Accord, seem to have been very successful, as documented in Fatum and Hutchinson (2005) and Huang and Neum (2006). Indeed, the BOJ recognized the relevance of the stabilisation of the exchange rate, as its monetary policy was based in the reduction of short-run interest rates as a

\footnotetext{
${ }^{13}$ Schwartz (2000) argues that the strong Yen did not weaken as a result of interventions and sterilisation of Dollar purchasing. However, Pinto de Andrade and Divino (2005) attribute a major role to exchange rates in accounting for cyclical patterns of the interest rate. In this sense, the Bank of Japan appears to have attempted to stabilize the exchange rate via interest rates.
} 
response to the growing external surplus and the subsequent appreciation of the Yen. This policy accelerated the increase of the asset prices until the collapse of the bubble. In fact, Hetzel (2004) pointed out that the initial shock had a monetary character. In addition, Leigh (2004) detected several negative monetary shocks in that period, something that could have been justified by the desire of the Japanese monetary authorities for a de facto smaller flexibility of the exchange rate.

\section{Credibility and speculative pressures}

In this section we study the degree of credibility for the implicit band regimes suggested by the analysis developed in the previous section and we check the degree of exchange market pressure for the Yen/Dollar exchange rate.

Regarding the credibility for the period going from 30 April to 31 December 1980 , the implicit central parity is estimated by a least squares regression in which only a trend and a constant are included. The estimated central parity is shown in Figure 3. It should be noted in passing that this central parity coincides with the equilibrium Yen/Dollar rate for the year 1980 as suggested in Ito (1992, Figure 10.2). A band of $\pm 6 \%$ is considered to include all observations falling within it during the aforementioned period ${ }^{14}$. From the analysis carried out in the previous section and from OECD reports, we assume a constant appreciation of the Yen/Dollar exchange rate within the implicit fluctuation bands.

As for the period going from 23 February to 18 October 1987, following Funabashi (1989) and Esaka (2000) we assume a target zone with a central rate of $153.50 \mathrm{Yen} /$ Dollar and a band of $\pm 5 \%$, being the central rate, which was rebased on 7 April 1987 up to $146 \mathrm{Yen} /$ Dollar to reflect new market conditions. The latter central parity is consistent with the results reported in Bergsten and Chen (1987), suggesting an equilibrium Yen/Dollar rate of 140-145 during 1987. Figures 5 and 6 illustrate the evolution of the Yen/Dollar exchange rate, adding the central parities and the band for the two periods studied.

\section{[Figures 5 and 6, here]}

Credibility is analysed using three indicators: the Svensson simple test, the drift adjustment method and an inverse measure of the probability of realignment. Svensson (1991) provided a simple test to study the credibility of a target zone exchange rate regime with fluctuation bands. We calculate a $100 \%$ confidence interval for the expected rate of realignment of the Yen/Dollar exchange rate using the three-month interbank rate. Taking into account the uncovered interest parity hypothesis, the expected rate of realignment is bounded according to:

$i_{t}-i_{t}^{*}-\left(\bar{x}_{t}-x_{t}\right) / \tau \leq E_{t}\left[\Delta c_{t+\tau}\right] / \tau \leq i_{t}-i_{t}^{*}-\left(\underline{x}_{t}-x_{t}\right) / \tau$

where $\mathrm{x}_{\mathrm{t}}$ is the deviation of the log exchange rate $s_{t}$ from the $\log$ central parity $c_{t}, \underline{x}_{t}$ and $\bar{x}_{t}$ are the lower and upper bounds of the exchange rate bands, $\tau$ is the maturity (valued

\footnotetext{
${ }^{14}$ This band has been chosen as an exploratory proposal and hence the results must be interpreted in relative terms, i.e. as a comparison of the different subperiods during the period studied, in this case 1980.
} 
at $3 / 12$ for a 3 -month maturity), $i-i^{*}$ is the interest rate differential and $E[\cdot]$ is the expectation operator.

The results of this test for 1980 and 1987 are shown in Figures 7 and 8 respectively. As can be seen in both cases, the hypothesis of a realignment expectation equals to zero cannot be rejected. Nonetheless, in 1980 the expected rate of revaluation grows during the early part of the period, reaching its highest values around June. This behaviour was probably related to trader caution due to the upcoming parliamentary elections on 22 June, particularly in view of the sudden death of Prime Minister Ohira which added further uncertainty to the election campaign. The lowest values of the expectation of revaluation occur in August, most likely due to the outbreak of hostilities between Iran and Iraq [see, e. g., (Pardee, 1980, 1981) and (OECD, 1980, 1981)]. Furthermore, in the case of 1987 this measure could reflect both the existence of revaluation expectations at the end of March, just before the supposed change in central parity from 153.5 to 146 Yen/Dollar, and of the expectations of devaluation of the Yen at the end of July.

[Figures 7 and 8, here]

The second indicator to gauge the degree of credibility is the drift adjustment method. This method, originally proposed by Bertola and Svensson (1993), computes an econometric estimate of the expectations of economic agents regarding the realignment. These realignment expectations constitute an inverse measure of credibility. The procedure involves estimating the expected rate of variation of the exchange rate within the band in the absence of realignment, and then computing the expected rate of realignment $g_{t}^{\tau}$. Once $g_{t}^{\tau}$ has been estimated, the corresponding $90 \%$ confidence intervals can be calculated.

In this paper we have estimated the expected rate of depreciation within the bands using a linear regression model where the exchange rate and the domestic and foreign interest rates are taken as explanatory variables:

$$
\frac{x_{t+\tau}-x_{t}}{\tau}=\sum_{j} \alpha_{j} d_{j}+\beta_{1} x_{t}+\beta_{2} i_{t}^{*}+\beta_{3} i_{t}+\varepsilon_{t+\tau}
$$

where $x_{t+\tau}$ and $x_{t}$ are the exchange rate $(\log )$ deviation from the central parity at times $t+\tau$ and $t$, respectively. In the case of the 1987 bands, the variables $d_{j}$ denote the dummies for the subperiods defined by the realignment on 7 April suggested by Esaka (2000).

Figures 9 and 10 show the expected rate of realignment and the $90 \%$ confidence intervals for the studied periods of 1980 and 1987, respectively. As for the year 1980, expectations of revaluation are confirmed as increasing in May and June, as well as in December, following the announcement early that month by the Ministry of Finance that it would increase the quotas available to Japanese and foreign banks for swapping Dollar borrowing into Yen. This announcement gave more scope for capital inflows and improved market sentiment for the Yen. The expected rates of realignment greater than zero are obtained in August. With respect to 1987, the method enables us to reject the hypothesis of null expectations of a realignment during the more critical stages of the period studied. Thus, it clearly reflects both the expectations of revaluation in March, 
May-June and August-September, and the expectations of devaluation in July and October. These results are very similar to those obtained by Esaka (2000, p. 123).

[Figures 9 and 10, here]

Lastly, the probability of non-realignment is obtained using Logit estimation. Here we have introduced the exchange rate, the distance to central parity and the interest rate differential as the explanatory variables. The selection of these variables stems from our interest in estimating credibility with high frequency data.

Assuming there is no credibility when $y_{t}=0$ and that when $y_{t}=1$ there is credibility, we use the drift-adjustment method to design the Logit model. As explained above, the method estimates the $90 \%$ confidence interval. If both limits of the interval were simultaneously greater than, or less than, zero, the agents would have expected realignments with $90 \%$ confidence and $y_{t}=0$, otherwise $y_{t}=1$.

The probabilities estimated from the exchange rate, distance to central parity and the interest rate differential (not shown here to save space, but available from the authors upon request) suggest that, when the exchange rate is used as the explanatory variable in estimating the probability of non-realignment, May 1980 could be classified as a low-credibility month. When distance to central parity is used, credibility is reduced in August and at the beginning of December 1980. Finally, there is evidence of an increase in credibility from August until December, with some marginal credibility losses in October and December.

Regarding the 1987 period, when the exchange rate is used, the probability of non-realignment would have been lower at the end of February and in March 1987, as well as at the end of July and the early days of August of that year. Alternatively, when using the distance of the exchange rate to the central parity, the results suggest that the probability of realignment is higher during May and in the latter part of July. Finally, the use of the interest rate differential confirms the lowest credibility in March, as well as suggesting marginal credibility losses in July.

In recent years a number of researchers have claimed success in predicting currency crises. To that end, a definition of crisis has been necessary. Therefore, as a complementary analysis of the credibility measures, we calculate two exchange market pressure indices in order to know how robust the bands were. Both indices are weighted average of monthly percentage depreciations and monthly percentage reductions in reserves $^{15}$. Both indices increase just before the beginning of the subperiod of 1980 (Figures 11 to 14). In fact, they exceed the critical level in one case, and decrease all during 1980. This suggests that the implicit band could have mitigated the speculative behaviour in the exchange market. The implications for the 1987 subperiod are less clear.

[Figures 11 and 14, here]

\footnotetext{
${ }^{15}$ The weights used by Edison (2003) incorporate the standard deviations of the exchange rate and the reserves, while Kaminsky et al (1998) introduce the standard deviations of the variations of the exchange rate and the reserves. Furthermore, in the first paper the critical level to consider a currency crisis is the mean plus 1.5 times the standard deviation of the index, while in the second one is the mean plus 3 times the standard deviation of the index.
} 


\section{Concluding remarks}

In this paper we have attempted to identify implicit exchange rate regimes for the Yen/Dollar. This particular rate was chosen because it is generally viewed as being the most flexible of all the exchange rates in the world economy. Confirmation of the existence of such regimes has major empirical implications given the widespread comparative use made of the rate.

To that end, we have applied different statistical approaches to data covering the period 1971-2003. Our results indicate that implicit regimes, excluding flexible ones, would have seemed to exist. An approach based on the use of exchange rate data to find de facto bands suggests that such regimes are present, but the results obtained are not informative. A more realistic method considers central bank interventions in the foreign exchange markets in order to study the intention (and efficacy) in maintaining the exchange rate within certain limits.

A directional prediction test has been applied, as standard time-series techniques may not be well suited to the study of the relationship between exchange rates and foreign exchange interventions. This test considerably restricts the implicit band regimes for the Yen/Dollar exchange rate. In the case of the Fed, the intention and efficacy of interventions are suggested for two subperiods: April-December 1980 and March-October 1987, the latter coinciding with the Louvre Accord.

To the extent that the market learns about the intentions behind central bank stabilizing interventions, an announcing hypothesis can also be considered. A study of the credibility of implicit bands was therefore undertaken for both subperiods mentioned above. Several critical events for the Yen/Dollar exchange were detected. For the episode of implicit bands detected for the year 1980, all the indicators reflect a lack of credibility in June, August and December. For the period identified around the Louvre Accord in 1987, there is evidence of credibility losses in May and June. For the remaining subperiods, the credibility indicators suggest a high degree of confidence by agents regarding the exchange rate's evolution within the implicit bands. This, in turn, could be considered to be further evidence supporting the existence of implicit fluctuation bands that compromised the behaviour of the Fed and the Bank of Japan in the exchange rate markets.

This paper has demonstrated the potential usefulness of a sequential procedure to detect implicit bands, taking into account both the dynamics of the exchange rate and the interventions of central banks. In our opinion, the results obtained suggest that further consideration of this procedure for other exchange rates could prove to be a fruitful exercise.

From the empirical point of view, central banks should be more transparent when communicating their interventions in foreign exchange markets, even providing researchers with the actual data involved in these operations. Where this is not possible, extensive literature exists to suggest alternative, more realistic measures of interventions other than changes in foreign reserves [see, e. g., Quirk (1977), Dornbusch (1980), Gärner (1987) and Hodgman and Resek (1987)]. 


\section{References}

Bean, C. (1992) "Economic and Monetary Union in Europe", Journal of Economic Perspectives, Vol. 6, pp. 101-121.

Bergsten, C. F. and R. C. William (1987) The United States-Japan Economic Problem, Washington, D.C.: Institute for International Economies.

Bertola, G. and R. J. Caballero (1992) "Target Zones and Realignments", American Economic Review, Vol. 82, pp. 520-536.

Bertola, G. and L. E. O. Svensson (1993) "Stochastic Devaluation Risk and the Empirical Fit of Target Zone Models", Review of Economic Studies, Vol. 60, pp. 689-712.

Bomhoff, E. J. (1987) “The Dollar-yen Exchange Rate", Bank of Japan Monetary and Economic Studies, Vol. 5, pp. 1-32.

Calvo, G. and C. Reinhart (2002) "Fear of Floating", Quarterly Journal of Economics, Vol. 117, pp. 379-408.

Cargill, T. F., Hutchinson, M. M. and T. Ito (1997) The Political Economy of Japanese Monetary Policy, Cambridge, Mass.: The MIT Press.

Chang, R. and A. Velasco (2000) "Exchange Rate Policy for Developing Countries", American Economic Review, Papers and Proceedings, Vol. 90, pp. 71-75.

Chen, L. and Huang, X. (2007): "The Effectiveness of Joint Intervention on the Yen/US Dollar Exchange Rate", Applied Economics Letters, Vol. 15, pp. 375-378.

Cooper, R. N. (1999) "Exchange Rate Choices", in J. S. Little and G. P. Olivei, eds., Rethinking the International Monetary System, Federal Reserve Bank of Boston, Conference Series No. 43, pp. 99-123.

Coudert, V. and M. Dubert (2004) “Does Exchange Rate Regime Explain Differences in Economic Results for Asian Countries?", Working Paper No 2004-05, Centre d'Estudes Prospectives et d'Informations Internationales, Paris.

De Grauwe, P. (2000) Economics of Monetary Union, Fourth edition, Oxford: Oxford University Press.

Dominguez, K. (1993) "Does Central Bank Intervention Increase the Volatility of Foreign Exchange Rates?”, Working Paper 4532, National Bureau of Economic Research, Cambridge, Massachusetts. 
Dominguez, K. (2003) "When Do Central Bank Interventions Influence Intra-Daily and Longer-Term Exchange Rate Movements?”, Working Paper 9875, National Bureau of Economic Research, Cambridge, Massachusetts.

Dominguez, K. and J. Frankel (1993) "Does Foreign Exchange Intervention Work? The Portfolio Effect", American Economic Review, Vol. 83, pp. 13561369.

Dornbusch, R. (1980) “Exchange Rate Economics: Where Do We Stand?”, Brooking Papers on Economic Activity, Vol. 1, pp. 143-185.

Edin, P-A and A. Vredin (1993) "Devaluation Risk in Target Zones: Evidence from the Nordic Countries", The Economic Journal, Vol. 103, pp. 161-175.

Eichengreen, B. (1994) International Monetary Arrangements for the $21^{\text {st }}$ Century, Washington, DC: The Brookings Institution.

Eichengreen, B. (2000) “The EMS Crisis in Retrospect”. Working Paper 8035, National Bureau of Economic Research, Cambridge, Massachusetts.

Esaka, T. (2000) "The Louvre Accord and Central Bank Intervention: Was There a Target Zone?", Japan and the World Economy, Vol. 12, pp. 107-126.

Fatum, R. and M. M. Hutchison (2003) "Is Sterilised Foreign Exchange Intervention Effective After All? An Event Study Approach", The Economic Journal, Vol. 113, pp. 390-411.

Fatum, R. and M. M. Hutchison (2005) "Effectiveness of Official Daily Foreign Exchange Rate Intervention Operations in Japan", Journal of International Money and Finance, Vol. 25, pp. 199-219.

Fisher, S. (2001) "Exchange Rate Regimes: Is the Bipolar View Correct?", Journal of Economic Perspectives, Vol. 15, pp. 3-24.

Frankel, J. (1999) "No Single Currency is Right for all Countries or at all Times". Essays in International Finance No. 215, Princeton, New Jersey: Princeton University Press.

Frenkel, M., Pierdzioch, C., and G. Stadtmann (2004) "On the Determinants of Small and Large Foreign Exchange Market Interventions: The Case of the Japanese Interventions in the 1990s", Review of Financial Economics, Vol. 13, pp. 231243.

Funabashi, Y. (1989) Managing the Dollar: From the Plaza to the Louvre, Washington, D.C.: Institute for International Economics.

Gärner, M. (1987) "Intervention Policy Under Floating Exchange Rates: An Analysis of the Swiss Case", Economica, Vol. 54, pp. 439-453. 
Huang, Z. and S. Neun (2006) "The Effectiveness of Fed Interventions on the USD/DM Foreign Exchange Market”, Global Economy Journal, Vol. 6(2), Article 3.

Hetzle, R. L. (1999) “Japanese Monetary Policy: A Quantity Theory Perspective", Federal Reserve Bank of Richmond Economic Quarterly, Vol. 85, No. 1, pp. 125 .

Hodgman, D. R. and R. W. Resek (1987) "Central Bank Exchange Rate Policy”, in D. R. Hodgman and G. E. Wood, eds., Monetary and Exchange Rate Policy, London: MacMillan, pp. 136-192

Ito, T. (1992) The Japanese Economy, Cambridge, Mass.: The MIT Press.

Ito, T. (2002) "Is Foreign Exchange Intervention Effective?-The Japanese Experiences in the 1990s", Working Paper 8914, National Bureau of Economic Research, Cambridge, Massachusetts.

Ito, T. and T. Yabu (2004) "What Promotes Japan to Intervene in the Forex Market?", Working Paper 10456, National Bureau of Economic Research, Cambridge, Massachusetts.

Jeon, B. N: and Lee, E. (2002): "Foreign Exchange Market Efficiency, Cointegration, and Policy Coordination", Applied Economics Letters, Vo. 9, pp. 61-68.

Kaminsky, G., Lizondo, S. and C. M. Reinhart (1998) "Leading Indicators of Currency Crises", IMF Staff Papers, Vol. 45, pp. 1-48.

Kempa, B. and M., Nelles (1999) "The Theory of Exchange Rate Target Zones", Journal of Economic Surveys, Vol. 13, pp. 173-210.

Krugman, P. R. (1991) “Target Zones and Exchange Rate Dynamics”, Quarterly Journal of Economics, Vol. 106, pp. 669-682.

Levy-Yeyati, E. and F. Sturzenegger (2000) "Classifying Exchange Rate Regimes: Deeds vs. Words", Working Paper 02/2000, Centro de Investigación en Finanzas, Universidad Torcuato Di Tella, Buenos Aires.

Levy-Yeyati, E. and F. Sturzenegger (2001) "Exchange Rate Regimes and Economic Performance", IMF Staff Papers, Vol. 47, Special Issue, pp. 62-98.

Nakamura, T. (1995) The Postwar Japanese Economy: Its Development and Structure, 1937-1994, Tokyo: University of Tokyo Press.

Neely, C. J. (2000) "Are Changes in Foreign Exchange Reserves Well Correlated with Official Intervention?” Review, Federal Reserve of St. Louis September/October, pp. 17-25.

OECD (1980) Japan, Paris: OECD Economic Studies, July. 
OECD (1981) Japan, Paris: OECD Economic Studies, July.

Quirk, P. J. (1977) "Exchange Rate Policy in Japan: Leaning Against the Wind", IMF Staff Papers, Vol. 24, pp. 642-664.

Pardee, S. E. (1980) "Treasury and Federal Reserve Foreign Exchange Operations. February-July 1980 Semiannual Report”, Quarterly Review, Federal Reserve Bank of New York, Autumm, pp. 28-46.

Pardee, S. E. (1981) "Treasury and Federal Reserve Foreign Exchange Operations, August 1980-January 1981 Semiannual Report”, Quarterly Review, Federal Reserve Bank of New York, Spring, pp. 54-74.

Pesaran, M. H. and P. Timmermann (1992) "A Simple Nonparametric Test of Predictive Performance”, Journal of Business and Economic Statistics, Vol. 10, pp. 461-465.

Poirson, H. (2001) "How Do Countries Choose Their Exchange Rate Regime?", IMF Working Paper 01/46, International Monetary Fund, Washington, D.C.

Pinto de Andrade, J. and J. A. Divino (2005) "Monetary Policy of the Bank of JapanInflation Target Versus Exchange Rate Target", Japan and the World Economy, Vol. 17, pp. 189-208.

Ramchander, S. and Sant, R. R. (2002); "The Impact of Federal Reserve Intervention on Exchange Rate Volatility: Evidence from the Futures Markets", Applied Financial Economics, Vol. 12, pp. 231-240.

Reinhart, C. M. (2000) “The Mirage of Floating Exchange Rates”, American Economic Review, Papers and Proceedings, Vol. 90, pp. 65-70.

Reinhart, C. M. and V. R. Reinhart (2003) "Twin Fallacies About Exchange Rate Policy in Emerging Markets", Moneda y Crédito, No. 216, pp. 11-29.

Reinhart, C. M. and K. S. Rogoff (2004) "The Modern History of Exchange Rate Arrangements: A Reinterpretation", Quarterly Journal of Economics, Vol. 119, pp. 1-48.

Schwartz, A. J. (2000) "The Rise and Fall of Foreign Exchange Intervention", Working Paper 7751, National Bureau of Economic Research, Cambridge, Massachusetts.

Summers, L. (2000) "International Financial Crises: Causes, Prevention, and Cures", American Economic Review, Papers and Proceedings, Vol. 90, pp. 1-16.

Suzuki, Y. (1987) The Japanese Financial System, Oxford: Clarendon.

Suzuki, Y. (1989) Japan's Economic Performance and International Role, Tokyo: University of Tokyo Press. 
Svensson, L. E. O. (1991) “The Simplest Test of Target Zone Credibility", IMF Staff Papers, Vol. 38, pp. 655-665.

Schwartz, A. J. (2000) "The Rise and Fall of Foreign Exchange Market Intervention", Working Paper 7751, National Bureau of Economic Research.

Taylor, M. P. (2004) “Is Official Exchange Rate Intervention Effective?”, Economica, Vol. 71, pp. 1-11.

Wan, J.-Y. and Kao, C.-W. (2008): "Effects of Japanese Intervention on Yen/Dollar Exchange Rate Volatility: A Conditional Jump Dynamics Approach", forthcoming in Applied Economics Letters. 


\section{Figure 1}

Test of the average monthly variations. Bands of $\pm 1 \%$

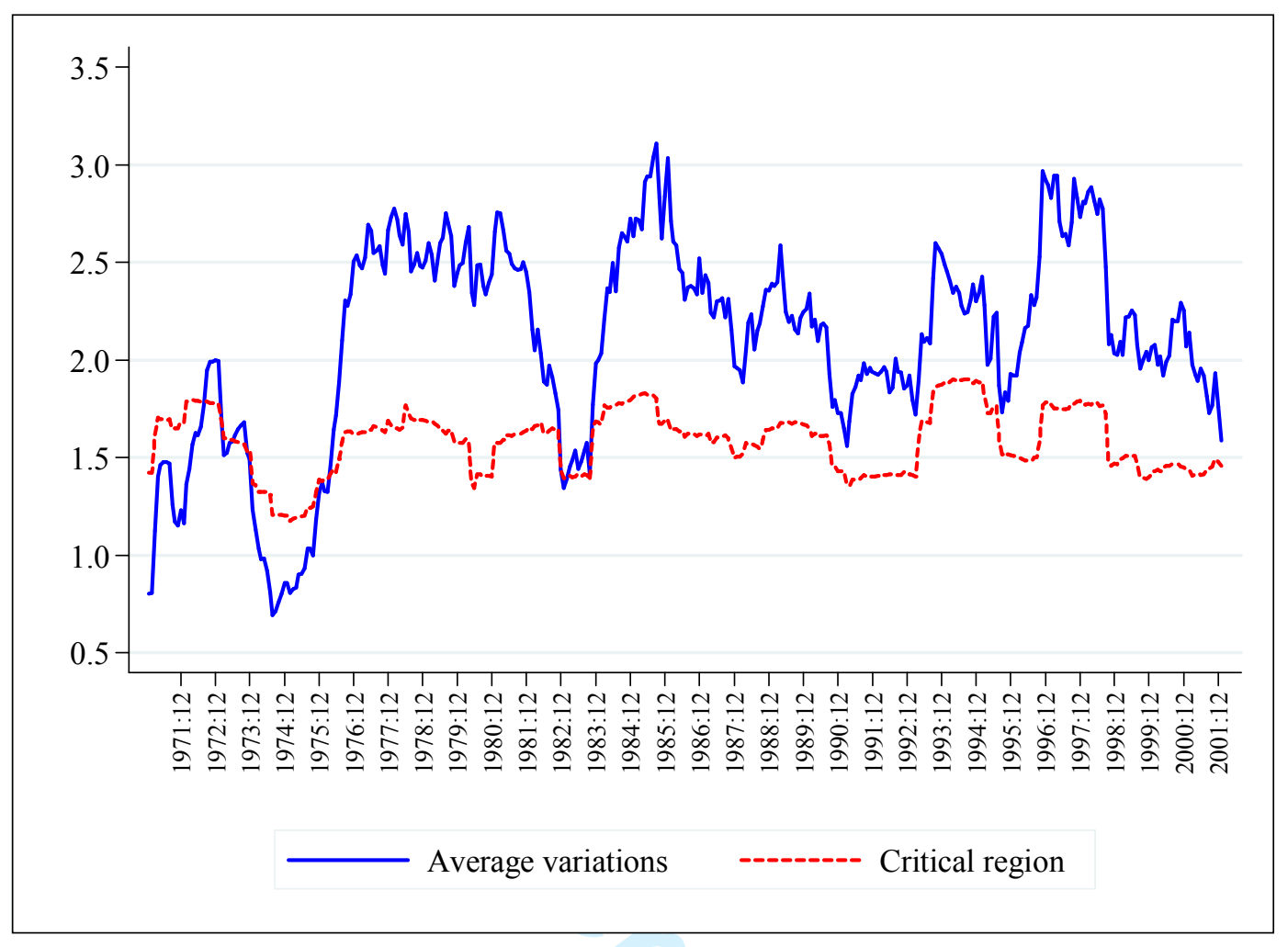




\section{Figure 2}

Test of the average monthly variations. Bands of $\pm 2 \%$

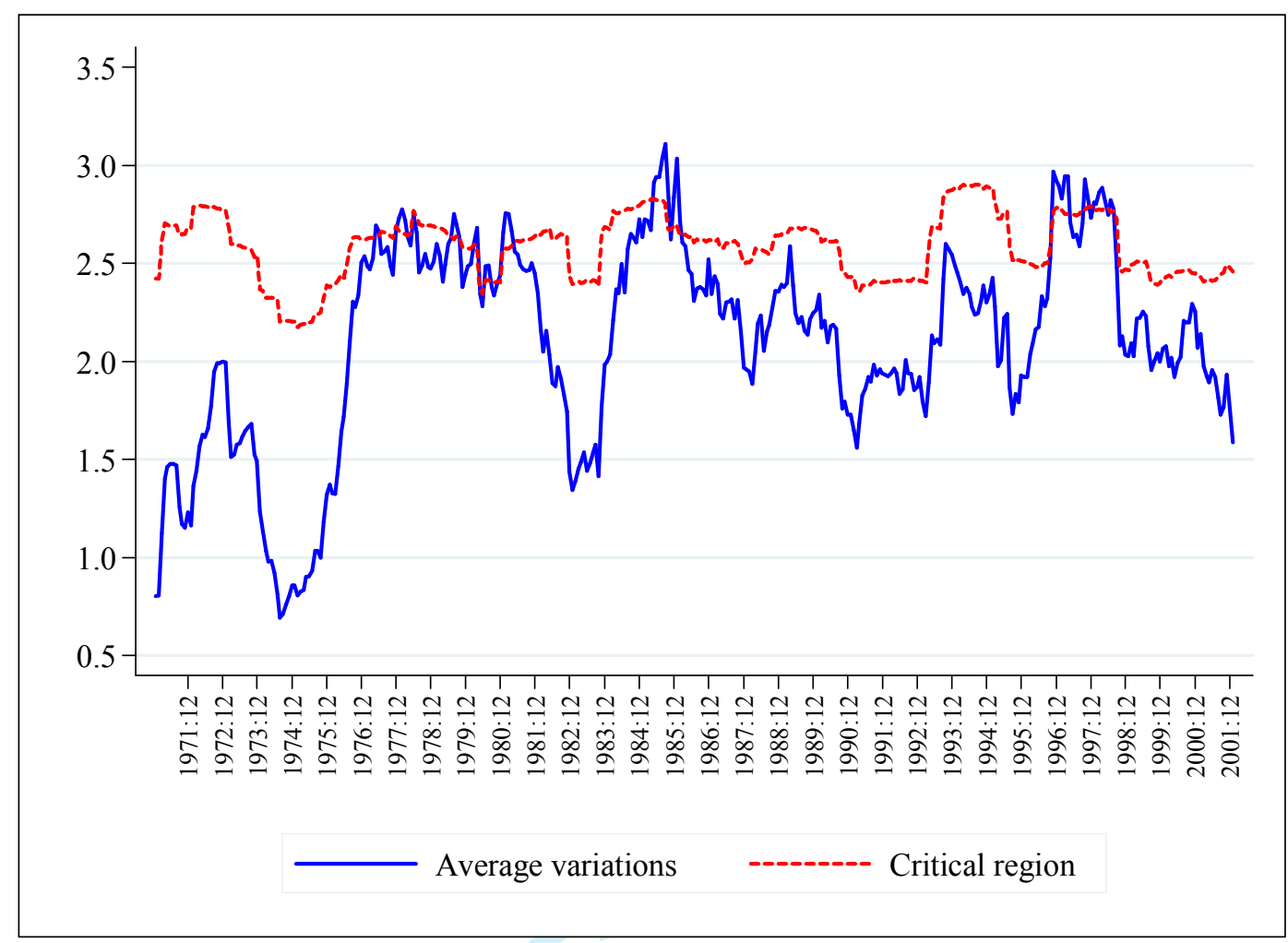




\section{Figure 3}

Test of the average monthly deviations from relative PPP. Bands of $\pm 1 \%$

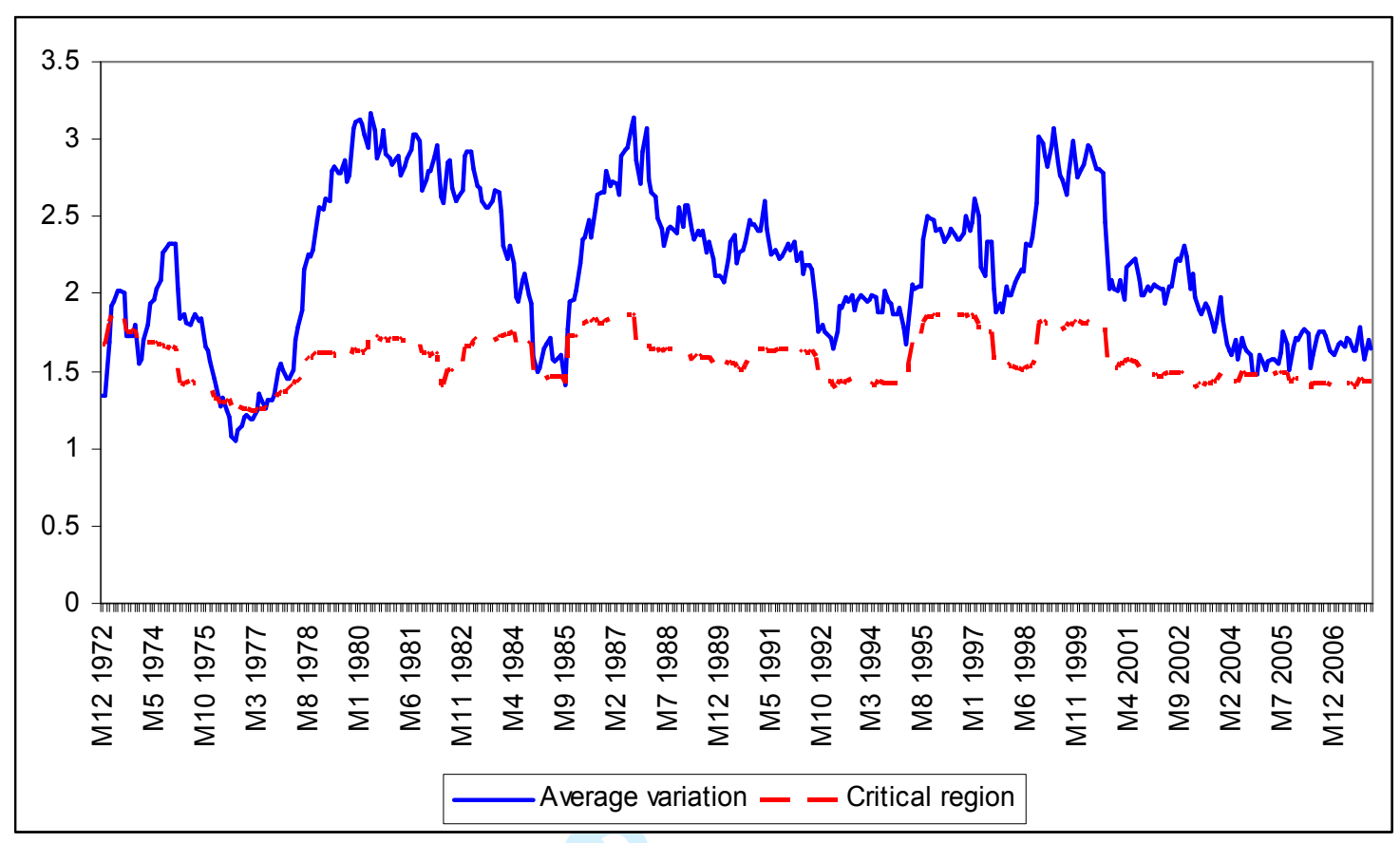




\section{Figure 4}

Test of the average monthly deviations from relative PPP. Bands of $\pm 2 \%$

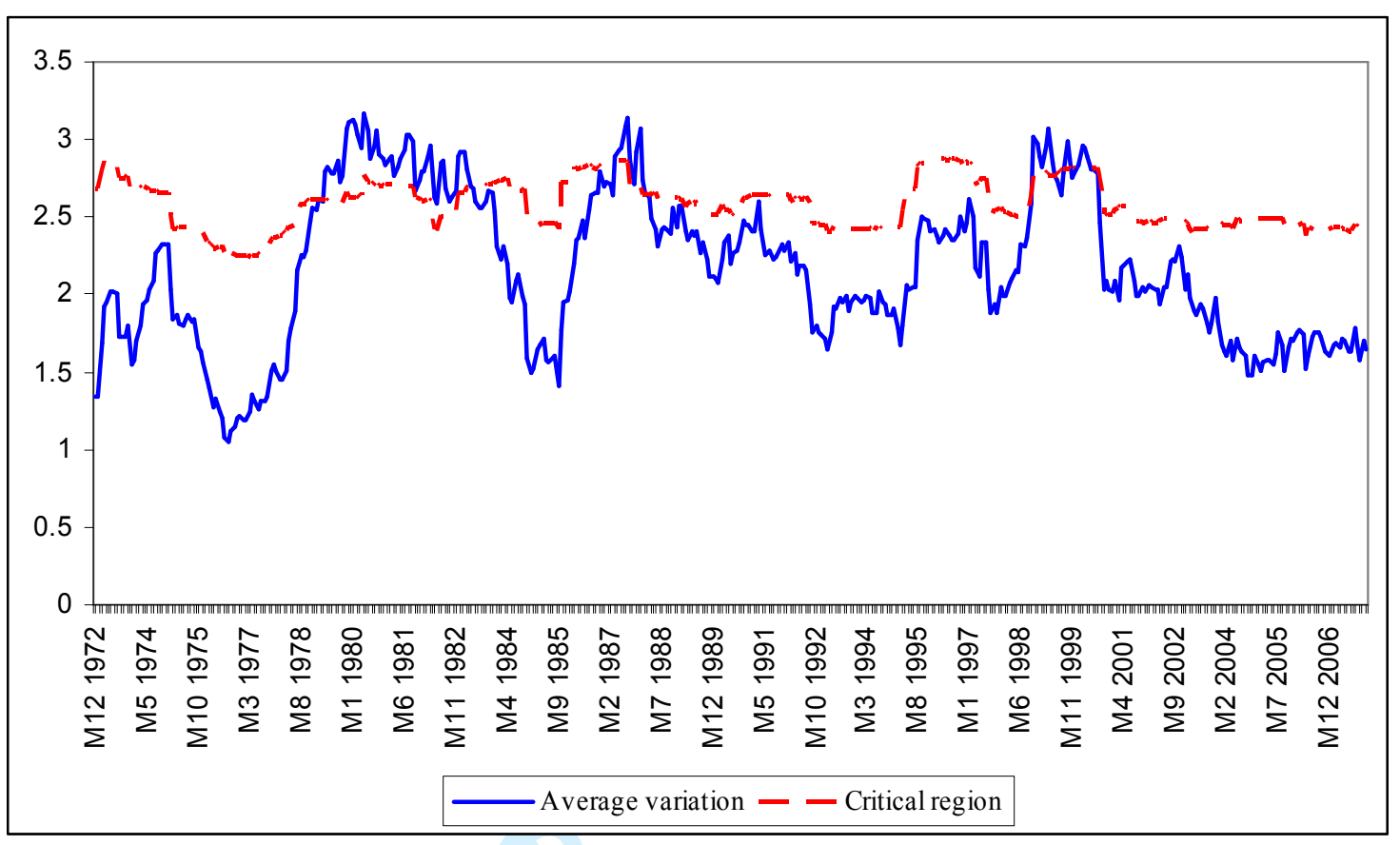


Figure 5

Yen/Dollar exchange rate, implicit central parity and bands (30 April 1980 to 31 December 1980)

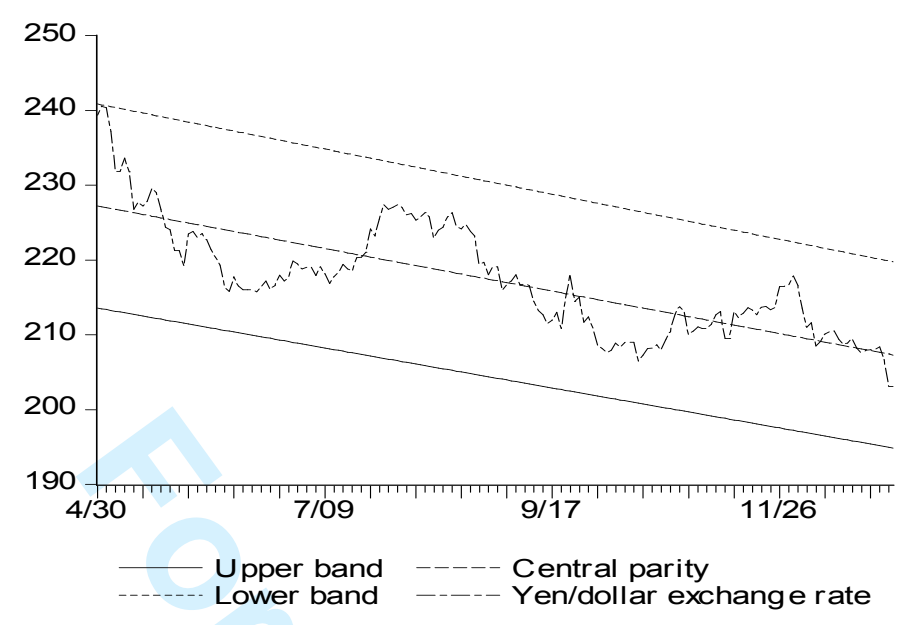

Figure 6

Yen/Dollar exchange rate, implicit central parity and bands (23 February 1987 to 18 October 1987)

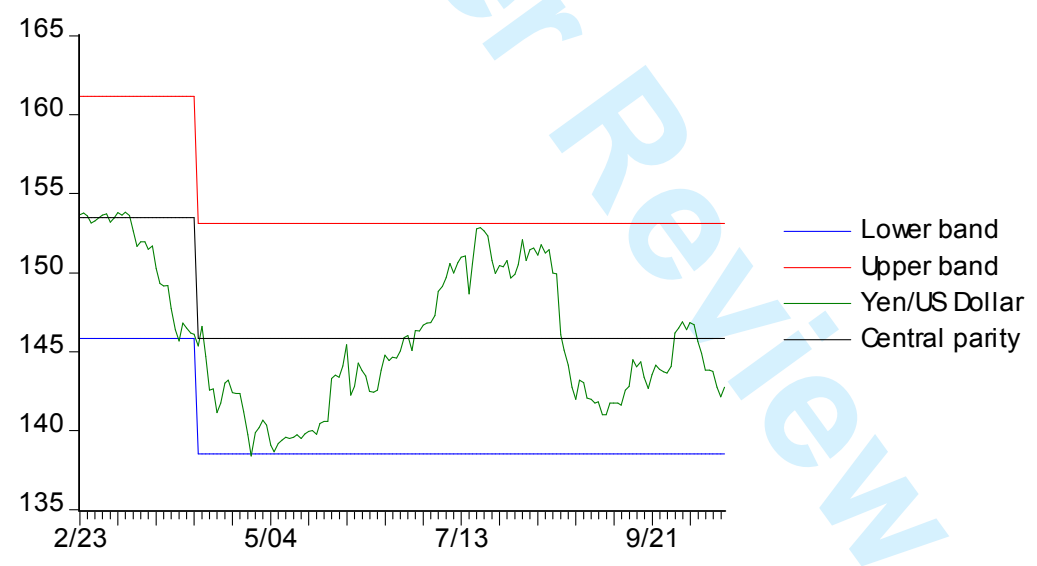




\section{Figure 7}

Svensson' test. $100 \%$ confidence interval

(30 April 1980 to 31 December 1980)

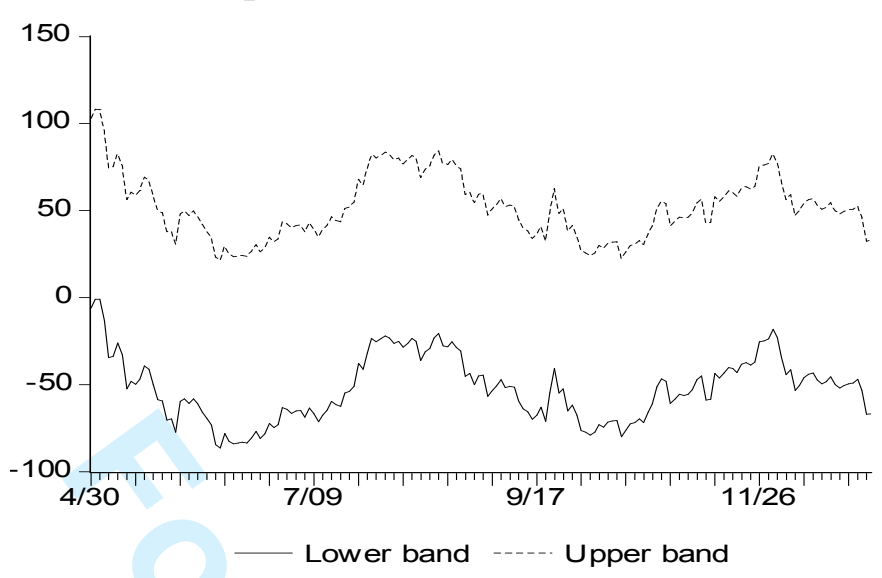

Figure 8

Svensson' test. $100 \%$ confidence interval (23 February 1987 to 18 October 1987)

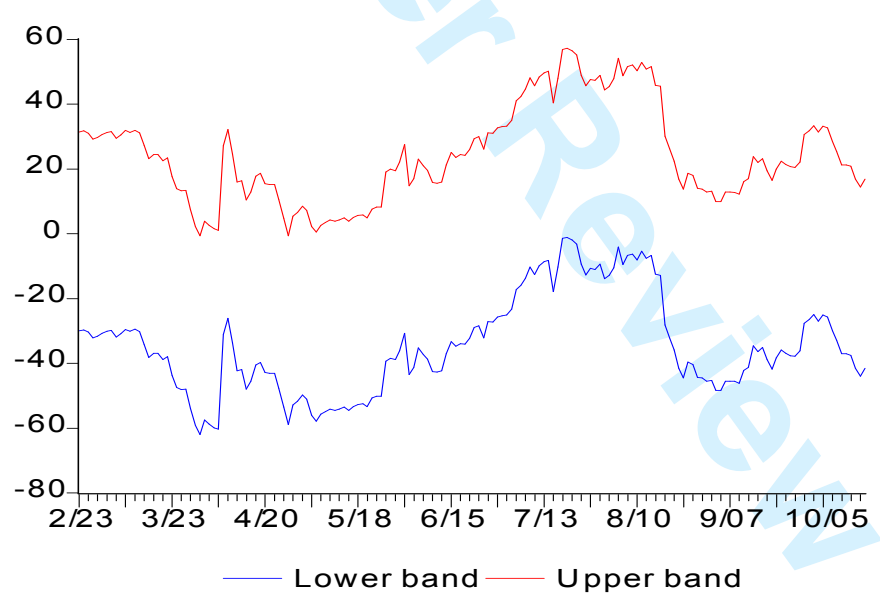


Figure 9

Drift adjustment method. $90 \%$ confidence interval (30 April 1980 to 31 December 1980)

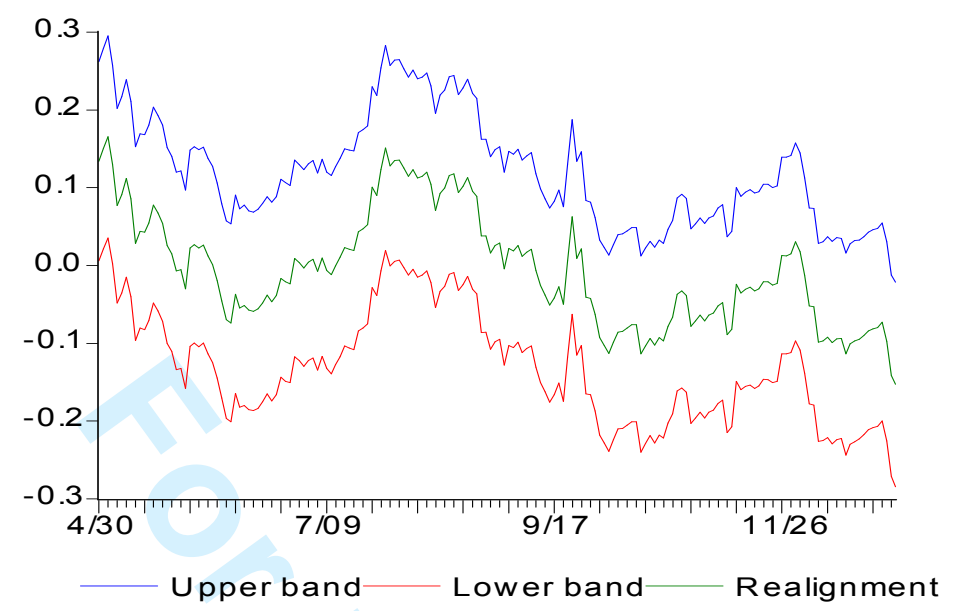

\section{Figure 10}

Drift adjustment method. $90 \%$ confidence interval (23 February 1987 to 18 October 1987)

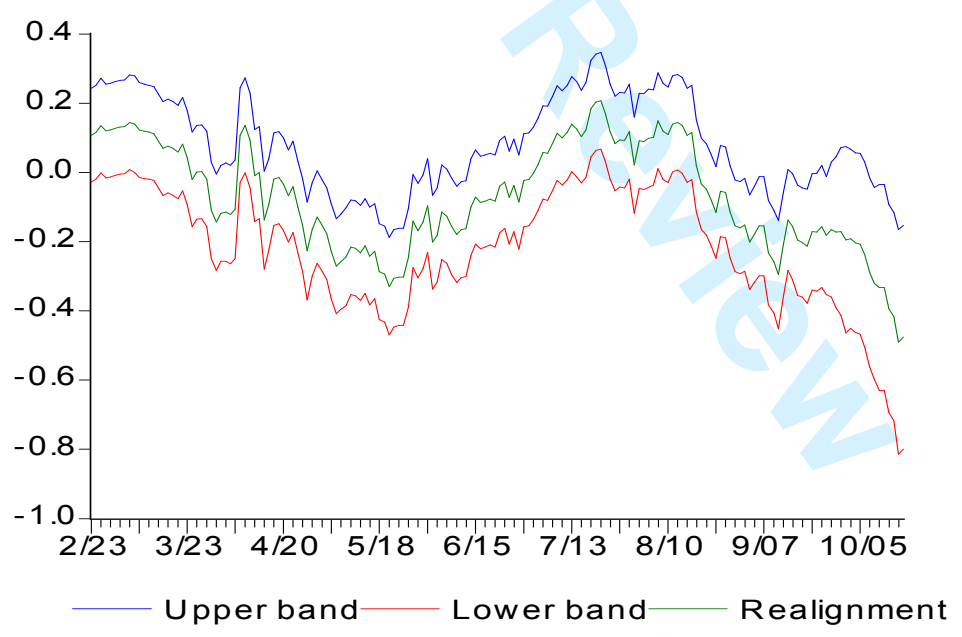




\section{Figure 11}

Japan. Exchange Market Pressure Index

Based on Edison (2003)

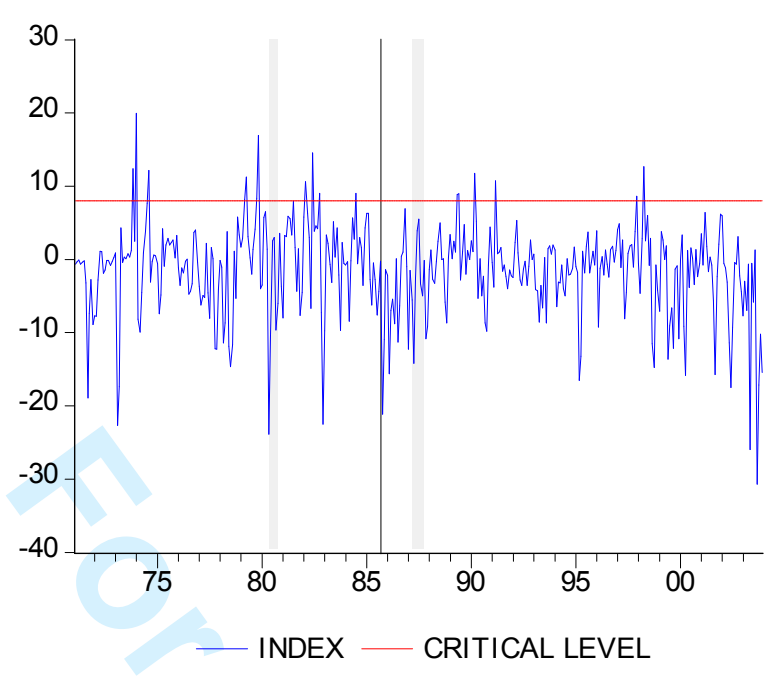

\section{Figure 12}

Japan. Exchange Market Pressure Index Based on Kaminsky et al (1998)

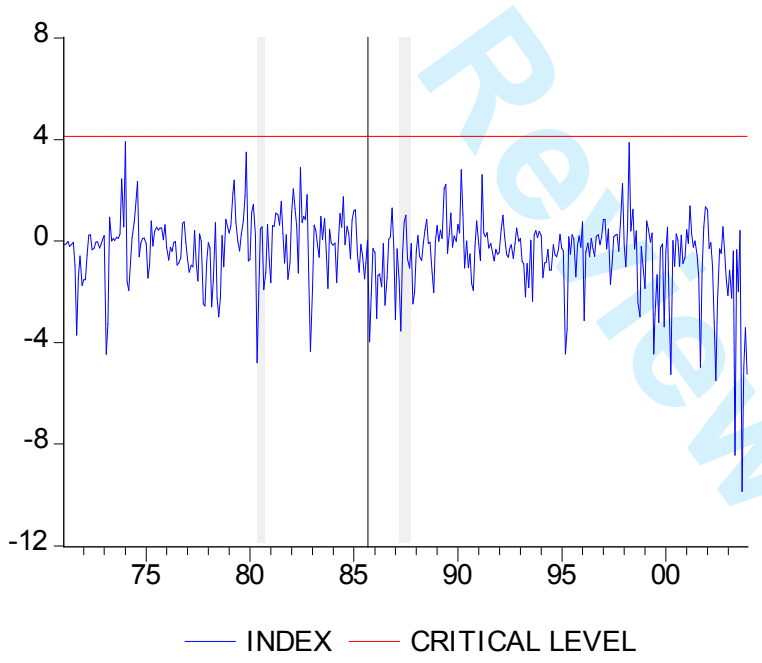




\section{$\underline{\text { Figure } 13}$}

\section{US Exchange Market Pressure Index Based on Edison (2003)}

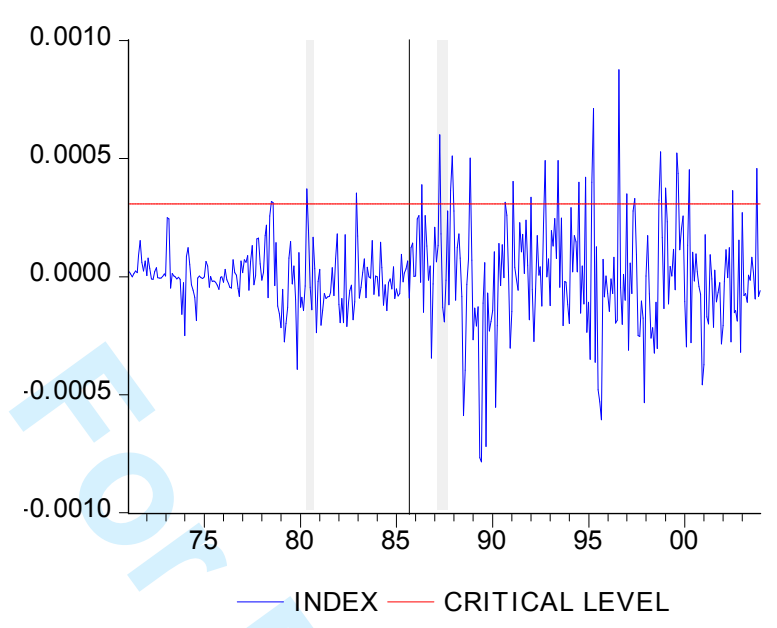

Figure 14

US Exchange Market Pressure Index

Based on Kaminsky et al (1998)

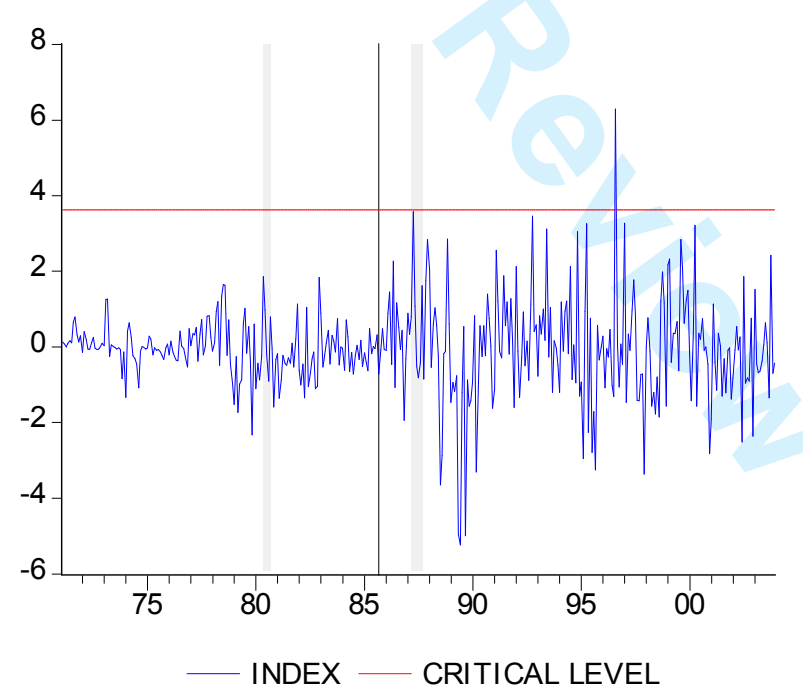


Table 1. Description of variables incorporated to the Pesaran-Timmermann test for the analysis of intention and efficacy

\begin{tabular}{|c|c|c|c|c|}
\hline Variables & Intention & & Efficacy & \\
\hline & Formulation & Description & Formulation & Description \\
\hline$y_{h}$ & $y_{h}=\log s_{h}-\log s_{h-k}$ & $\%$ depreciation of yen & $y_{h}=-\left(\log s_{h+k}-\log s_{h}\right)$ & $\%$ appreciation of yen \\
\hline$y_{h}>0$ & $I_{h}\left[y_{h}>0\right]$ & 1 if depreciation of yen, 0 otherwise & $I_{h}\left[y_{h}>0\right]$ & $\begin{array}{l}1 \text { if appreciation of yen, } 0 \\
\text { otherwise }\end{array}$ \\
\hline$\hat{y}_{h}$ & -intervenjap & Sales of $\$$ & -intervenjap & Sales of $\$$ \\
\hline$\hat{y}_{h}>0$ & $I_{h}\left[\hat{y}_{h}>0\right]$ & 1 if sale of $\$, 0$ otherwise & $I_{h}\left[\hat{y}_{h}>0\right]$ & 1 if sale of $\$, 0$ otherwise \\
\hline$y_{h} \cdot \hat{y}_{h}>0$ & $I_{h}\left[y_{h} \cdot \hat{y}_{h}>0\right]$ & $\begin{array}{l}1 \text { if purchase of } \$ \text { after appreciation } \\
\text { of yen or sale of } \$ \text { after depreciation } \\
\text { of yen; } 0 \text { otherwise }\end{array}$ & $I_{h}\left[y_{h} \cdot \hat{y}_{h}>0\right]$ & $\begin{array}{l}1 \text { if depreciation of yen } \\
\text { after purchase of } \$ \text { or } \\
\text { appreciation of yen after } \\
\text { sale of } \$ ; 0 \text { otherwise }\end{array}$ \\
\hline$p_{1}$ & $p_{1}=H^{-1} \sum_{h=1}^{H} I_{h}\left[y_{h}>0\right]$ & Probability of yen depreciation & $p_{1}=H^{-1} \sum_{h=1}^{H} I_{h}\left[y_{h}>0\right]$ & $\begin{array}{l}\text { Probability of yen } \\
\text { appreciation }\end{array}$ \\
\hline$\hat{p}_{1}$ & $\hat{p}_{1}=H^{-1} \sum_{h=1}^{H} I_{h}\left[\hat{y}_{h}>0\right]$ & Probability of sale of $\$$ intervention & $\hat{p}_{1}=H^{-1} \sum_{h=1}^{H} I_{h}\left[\hat{y}_{h}>0\right]$ & $\begin{array}{l}\text { Probability of sale of } \$ \\
\text { intervention }\end{array}$ \\
\hline$S R$ & $S R=H^{-1} \sum_{h=1}^{H} I_{h}\left[y_{h} \cdot \hat{y}_{h}>0\right]$ & $\begin{array}{l}\text { Probability of success under } \\
\text { dependence }\end{array}$ & $S R=H^{-1} \sum_{h=1}^{H} I_{h}\left[y_{h} \cdot \hat{y}_{h}>0\right]$ & $\begin{array}{l}\text { Probability of success } \\
\text { under dependence }\end{array}$ \\
\hline$S R I$ & $S R I=p_{1} \hat{p}_{1}+\left(1-p_{1}\right)\left(1-\hat{p}_{1}\right.$ & $\begin{array}{l}\text { Probability of success under } \\
\text { independence }\end{array}$ & $S R I=p_{1} \hat{p}_{1}+\left(1-p_{1}\right)\left(1-\hat{p}_{1}\right)$ & $\begin{array}{l}\text { Probability of success } \\
\text { under independence }\end{array}$ \\
\hline
\end{tabular}


Table 2

Pesaran-Timmermann Test

\begin{tabular}{|c|c|c|c|c|c|c|c|}
\hline \multirow[t]{2}{*}{ Months } & \multicolumn{7}{|c|}{ k-values (days) } \\
\hline & 1 & 5 & 10 & 20 & 30 & 40 & 60 \\
\hline \multicolumn{8}{|c|}{ Panel A: ex-post } \\
\hline 1980-Jan & 1.35 & 0.89 & -0.78 & 1.41 & 0.45 & & \\
\hline 1980-Mar & & & & & 2.00 & 2.00 & 2.00 \\
\hline 1980-Apr & 3.03 & 2.27 & 1.73 & 1.13 & 1.48 & 1.48 & 1.48 \\
\hline 1980-May & 1.59 & & & & & & \\
\hline 1980-Jul & 1.11 & 0.50 & -0.13 & 1.01 & 1.75 & 2.52 & 2.52 \\
\hline 1980-Aug & 0.88 & 0.76 & 0.76 & 1.78 & 4.01 & 4.01 & 4.01 \\
\hline 1980-Nov & 2.44 & 1.89 & 3.62 & -0.33 & 1.89 & 1.09 & 1.01 \\
\hline 1980-Dec & -0.80 & & & & 0.60 & 2.11 & 2.11 \\
\hline 1981-Jan & 1.20 & 2.25 & -1.52 & 0.95 & & & \\
\hline 1982-Oct & 0.71 & 0.71 & 0.71 & 0.71 & 0.71 & 0.71 & 0.71 \\
\hline 1987-Mar & 1.98 & 3.02 & 3.02 & 3.02 & 3.02 & 3.02 & 3.02 \\
\hline 1987-Aug & 2.14 & 2.86 & 2.14 & 2.86 & 2.86 & 2.86 & 2.86 \\
\hline 1988-Sep & 0.71 & 0.71 & & 0.71 & 0.71 & 0.71 & 0.71 \\
\hline 1989-Apr & 0.71 & 0.71 & 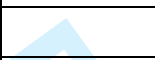 & 0.71 & 0.71 & 0.71 & 0.71 \\
\hline 1989-May & 1.50 & & & & & & \\
\hline 1989-Jun & & & 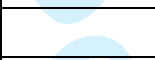 & & 2.00 & 2.00 & 2.00 \\
\hline 1989-Jul & 1.00 & & 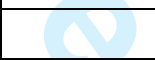 & & & & 1.00 \\
\hline 1990-Mar & & 1.41 & 1.41 & 1.41 & 1.41 & 1.41 & 1.41 \\
\hline \multicolumn{8}{|c|}{ Panel B: ex-ante } \\
\hline 1980-Jan & 0.78 & -1.81 & 0.45 & & & & \\
\hline 1980-Mar & & & & & & 2.00 & 2.00 \\
\hline 1980-Apr & -0.43 & -1.54 & & $V$ & & & \\
\hline 1980-May & -1.26 & 1.59 & & 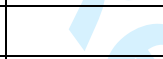 & & -0.60 & \\
\hline 1980-Jul & -1.26 & 1.75 & 1.75 & 2.52 & 1.75 & \begin{tabular}{|l|}
-0.19 \\
\end{tabular} & \\
\hline 1980-Aug & 1.14 & -0.54 & -0.29 & & & & \\
\hline 1980-Nov & -0.63 & 0.92 & 1.09 & -0.33 & 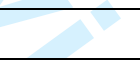 & & \\
\hline 1980-Dec & 0.60 & -0.40 & & & & & -0.40 \\
\hline 1981-Jan & -1.20 & 0.92 & 1.34 & 0.51 & - & & \\
\hline 1982-Oct & & 0.71 & 0.71 & & 0.71 & 0.71 & 0.71 \\
\hline 1987-Mar & 0.66 & & & & & 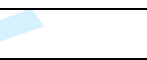 & 0.43 \\
\hline 1987-Aug & 0.48 & -0.65 & 2.09 & 2.86 & 2.86 & 2.09 & \\
\hline 1988-Sep & 0.71 & 0.71 & & 0.71 & 0.71 & 0.71 & 0.71 \\
\hline 1989-May & 0.85 & 0.47 & 0.37 & 0.47 & 0.75 & 0.66 & 0.47 \\
\hline 1989-Jun & & & & & 2.00 & & \\
\hline
\end{tabular}

